\title{
La Iglesia de San Pedro en Villacadima (Guadalajara)
}

\author{
Elena María Orta Garcia
}

\section{INTRODUCCIÓN. VILLACADIMA: CONTEXTO GEOGRÁFICO, HISTÓRICO Y CULTURAL}

El lugar de Villacadima se encuentra situado en la provincia de Guadalajara y pertenece a la Comunidad Autónoma de Castilla-La Mancha. Se halla enclavada en el noroeste de la provincia, muy cerca de los limites con las provincias de Segovia y Soria, situación geográfica que ha de ser tenida en cuenta si queremos entender el devenir histórico-artístico y cultural de esta villa.

El pueblo se halla situado al pie de un cerro con exposición al Sur. Según P. Madoz' el pueblo tenia 40 casas; la consistorial con habitación para cárcel, escuela de instrucción primaria, y una iglesia parroquial, San Pedro Apóstol. Confina el término con los de Cantalojas, Grado y Campisabalos; dentro de él se encuentran una fuente y las ermitas de Nuestra Señora del Campo y San Roque. El terreno es calizo y tiene buenos montes de pinares. Muy próximas al pueblo existen unas canteras, las

'P. Madoz. Diccionario geográfico-estadístico-histórico de España... Madrid, 1850, tomo XVI, págs. 99-100. 
canteras del Pinar, de la que se ha extraído la piedra para la construcción del pueblo.

En la producción, P. Madoz señala los cereales, algunas legumbres, madera y pastos, con los que se mantenía ganado lanar y vacuno, y caza de perdices, conejos y liebres.

En cuanto a la Historia de Villacadima, F. Layna Serrano, cronista oficial de la Provincia de Guadalajara, al hablar de la conquista y repoblación del país señala que «concluía el mes de mayo del año de gracia de 1085 cuando Alfonso VI se adueñó de Toledo, y poco antes o después cayeron en su poder las regiones norte y oeste de la actual provincia de Guadalajara, extremo que los cronistas de la época inmediatamente posterior no aclaran, pues sus noticias son escasas y confusas» ${ }^{2}$.

La población básicamente cristiana de la zona, a partir de 1085, sigue conviviendo y asimilando a la población musulmana existente con anterioridad, siendo en este ambiente de reconquista cristiana donde empiezan a construirse las iglesias en la vertiente Norte del Henares.

\section{LA IGLESIA PARROQUIAL DE SAN PEDRO APÓSTOL}

Está edificada en el centro del pueblo de Villacadima, hoy habitado solamente en épocas veraniegas y Semana Santa, muy abandonada, la iglesia, en los últimos años ha comenzado a ser reparada.

Se accede a ella a través de un amplio atrio descubierto. Es una bella iglesia románica con reformas posteriores. Es Monumento Nacional. Es una pequeña iglesia rural perteneciente al románico de la vertiente Norte del Henares que se halla muy próxima en cuanto a técnicas y estilo con otras de la zona, cuya situación en el conjunto provincial puede verse en la carta de dispersión del románico de esta zona en la figura 1.

Pertenece a la Diócesis de Sigüenza y actualmente no tiene culto.

2 Francisco Layna Serrano. La arquitectura románica en la provincia de Guadalajara. $1 .{ }^{a}$ ed. Madrid. Nuevas Gráficas, 1935, págs. 20-21. 


\section{La arquitectura}

\section{Exterior}

Los muros son de sillería.

En la fachada meridional, que se corresponde con el lado de la Epístola se halla la portada románica con arquivoltas de decoración vegetal.

La portada se inserta en un cuerpo saliente respecto a la fachada de la iglesia, hecho muy corriente en otras iglesias de la época de la región soriana. La cornisa de la portada está sostenida por una serie de ménsulas con sencilla decoración de bolas y rollos, salvo la central en la que aparecen esculpidas las llaves de San Pedro, y las dos extremas con cabezas de personajes, santos u obispos. Estos canecillos también son parecidos a los de otras iglesias de la región soriana como el de la ermita románica de los Santos Mártires de Garray, los de Caltojar, Nepas - Morcuera, o la portada románica de Osona.

La portada propiamente dicha es abocinada y con cuatro arquivoltas, ornamentadas la exterior y la interior y marco angrelado con rosetones ciegos, tres columnas con intercolumnio y capiteles de sencilla decoración geométrica se completa con un cancel de arco de medio punto. Aún conserva la puerta de madera con clavazón de hierro de la época.

En la fachada meridional se abren pequeñas ventanas de derrame exterior, una de ellas asimétrica posiblemente con la finalidad de permitir un mayor paso de la luz hacia el interior.

El ábside es cuadrado y se refuerza en sus ángulos con gruesos contrafuertes.

La cornisa se remata por su parte inferior con ménsulas muy senciIlas.

La fachada norte está bien labrada en sus sillares, con pequeñas ventanas en forma de saetera, que se observa estuvieron acristaladas.

La fachada occidental o de los pies debió tener una espadaña de tres vanos, dos de los cuales pueden verse aún aunque cegados y cuya reconstrucción ideal en alzado podría ser semejante al que reproducimos en la figura 2.

En esta fachada se alza una torre que tapó parte de la espadaña. Esta torre está construida con sillares muy bien labrados y es de airosas proporciones. 
En cuanto a la primitiva espadaña no debía diferir mucho de otras de la región soriana como la de Nepas, o la de la ermita de San Miguel de Gormaz o la de la fachada occidental de la parroquial de Arganza.

Interior

El interior es de tres naves, separadas por arcos apuntados sobre pilares rectangulares muy bajos; la central está cubierta por bóveda esquifada falsa y las laterales a cielo raso. (fig. 3)

Las bóvedas de la cabecera son de cruceria. Puede observarse un arco triunfal de medio punto. La bóveda de la Capilla Mayor es de crucería con trerceletes y de cuatro tramos.

Tiene un coro en alto a los pies, donde aún se conserva parte del órgano.

La sacristía de cielo raso se dispone al lado de la Capilla Mayor con la que se comunica por el lado del Evangelio.

En cuanto a la cronología de la primitiva iglesia tal vez habría que remontarla al siglo XII aunque la portada corresponde al siglo XIII, si bien no contamos hasta ahora con documentos fehacientes para esta atribución tan temprana.

\section{El arte sacro de la iglesia de San Pedro}

En la actualidad la iglesia de San Pedro de Villacadima se halla totalmente vacia y en proceso de restauración, solamente se conserva parte del portaje de madera y los restos del órgano, así como numerosas losas sepulcrales.

En el Museo Diocesano de Arte de Sigüenza ${ }^{3}$ se encuentran depositadas y expuestas las siguientes obras de arte sacro:

En la SALA G - (Románico-Gótico).

N. ${ }^{\circ}$ 95: CALVARIO. Tallas polícromas. Estilo románico con influencias bizantinas y góticas. Siglo XII, segunda mitad. Procedencia: Villacadima (Guadalajara).

3 Felipe Gil PeCes y Rata. Guia Histórica y Catálogo del Museo Diocesano de Arte. Sigüenza. Gráficas Carpintero-Sigüenza, 1982, págs. 21, 22, 28, 31, 32 y 33. 
En la SALA M - (Santa Marta) se encuentra expuesto el antiguo Sagrario de la Iglesia de San Pedro con el n. 164.

N. ${ }^{\circ}$ 164: SAGRARIO-OSTENSORIO. Madera y tallas polícromas. Estilo renacentista. Siglo XVI, último tércio. Escuela castellana. Procedencia: Villacadima (Guadalajara).

En la SALA N - (Salzillo) se hallan expuestas una imagen del Niño Jesús, un San Sebastián, la imagen de San Pedro bajo cuya advocación fue erigida la iglesia, una Piedad y una Virgen con el Niño.

N. ${ }^{\circ}$ 169: NIÑO JESÚS. Talla polícroma. Estilo naturalista. Siglo XVII. Procedencia: Villacadima (Guadalajara).

N. ${ }^{\circ}$ 170: SAN SEBASTIÁN. Talla polícroma. Estilo renacentista. UItimo tercio del siglo XVI. Procedencia: Villacadima (Guadalajara).

N. ${ }^{\circ}$ 177: SAN PEDRO APOSTOL. Talla polícroma. Estilo barroco. Primera mitad del siglo XVIII. Procedencia: Villacadima (Guadalajara).

N. ${ }^{\circ}$ 179: PIEDAD. Talla polícroma. Estilo manierista-miguelangelesco. Obra probable de Juan Picardo o sus discípulos. Tercer cuarto del siglo xVI. Procedencia: Villacadima (Guadalajara).

N. ${ }^{\circ}$ 181: VIRGEN CON EL NIÑO. Talla polícroma. Estilo renacentista. Al estilo de Francisco del Rincón. Ultimo tercio del siglo XVI. Procedencia: Villacadima (Guadalajara).

Por último en la ANTESALAS M-N (Miniaturas) se halla una imagen del «ECCE HOMO».

N. ${ }^{\circ}$ 144: «ECCE HOMO». Talla polícroma. Estilo barroco-naturalista. Siglos XVII-XVIII. Primera mitad. Escuela castellana. Procedencia: Villacadima (Guadalajara).

De todo el rico patrimonio de esta iglesia hoy cerrada y sin culto nos da una idea el primer Inventario de bienes (muebles) del año 1697 que recoge también otros inventarios de 1732 y 1733.

Dichos inventarios se encuentran archivados en el Archivo Diocesano de Sigüenza al que hemos tenido acceso gracias a la amabilidad de su director Don Felipe Gil Peces. También están archivados en este mismo archivo los libros de Heredades y Capellanías además de los propiamente parroquiales.

El contenido de estos libros, sumamente interesantes desde diversos puntos de vista no puede ser abordado dentro de los límites de este artículo. 
En el Inventario Artístico de Guadalajara y su provincia ${ }^{4}$ se indica que en el lado del Evangelio existe:

- Un retablo de tres calles y remate, del siglo XVII, que alberga una serie de lienzos del mismo siglo: Aparición de la Virgen a un Dominico, Santo Obispo, Virgen con Niño, Santo Papa y lienzo, en el remate, no identificado. Todos ellos en mal estado de conservación.

- Retablo del XVIII con tres hornacinas y columnas salomónicas, así como con inscripción en el banco que reza los nombres de los donantes de las imágenes que alberga, que son: Ecce Homo en busto, Crucificado y Virgen de la Soledad.

- Púlpito de excelente calidad, en piedra, del siglo XVI y con decoración de candelieri.

Según este mismo Inventario Artístico en la Capilla Mayor existía:

- Retablo Mayor del siglo xVII, de tres calles, remate y banco luciendo la siguiente decoración: en el banco, inscripción con fechas de "1659" y dos lienzos con dos Evangelistas cada uno; calle central, imagen de San Pedro; calles laterales, cuatro lienzos con escenas de la vida de San Pedro ("Quo vadis?», "Aparición de Cristo", "Crucifixión de San Pedro" y tema no identificado); remate, imagen de Inmaculada. Se completa el retablo mayor con Sagrario decorado con bajorrelieves de San Pedro, Cristo Resucitado y San Pablo.

En el lado de la Epístola, según el Inventario Artístico, se conservaba:

- Excelente escultura de la Piedad, de medianas proporciones y del siglo XVI.

- Retablo del siglo XVII, de tres calles y remate, albergante de serie de pinturas de la misma fecha: Cristo atado a la columna, Cristo bendiciendo, Cristo despojado de sus vestiduras y Virgen.

- Retablo popular con pintura en su remate (no identificable) y escultura de Virgen con Niño, del siglo XIII, procedente de la Ermita de la Virgen del Campo.

- Retablo rococó, del siglo XVIII, con esculturas populares de San José y San Julián.

4 Inventario Artístico de Guadalajara y su provincia, dirigido por José María de Azcarate Ristori. Centro Nacional de Información Artistica, Arqueológica y Etnológica. Madrid, 1983, tomo II, págs. 330-331. 
Y en la Sacristía se hallaban:

- Cruz Procesional del siglo xv.

- Cajoneria barroca.

- Esculturas del siglo XVI de Virgen con Niño y San Sebastián.

- Imagen popular del Niño Jesús de Praga.

También se dice en este mismo Inventario que en el suelo del lado del Evangelio y de la nave central se conservan landas sepulcrales, algunas con escudos, entre las que destaca una gótica (de inscripción ilegible) y otra barroca (fechada en «1710"), que se encontraban bajo los escombros.

También se hace el inventario de una pila bautismal, del siglo XVI, con gallones.

Ya hemos hecho referencia a la conservación de algunas de estas imágenes en el Museo Diocesano de Sigüenza.

En el atrio de la iglesia, y utilizado como escalón para bajar a la calle que existe por detrás del ábside, hemos localizado parte de una inscripción gótica que ha sido estudiada por el Profesor Blas Casado. 


\section{BIBLIOGRAFIA}

AlColeA, S.: Guia artística de Soria y su provincia. Barcelona, 1964.

AzCARATE RistoRI, J. M.: Inventario Artístico de Guadalajara y su provincia. Madrid, Centro Nacional de Información Artística, Arqueológica y Etnológica. Rivadeneyra, S.A., 1983, 2 tomos.

Camps Cazorla, E.: El arte románico en España. Barcelona, Edit. Labor, 1935.

DuRLIAT, M.: El arte románico en España. Barcelona, 1964.

EnRIQUez de SALAmANCA, C.: Rutas del románico en la provincia de Soria. Las Rozas (Madrid), 1986, 143 páginas.

FloREZ, E. y varios continuadores: España Sagrada. Madrid, Academia de la Historia, 1747-1918, 52 volúmenes.

Gaya Nuño, J. A.: El románico en la provincia de Soria. Madrid, 1946.

Gomez Moreno, M.: El arte románico español: esquema de un libro. Madrid, Centro de Estudios Históricos, 1934.

Gudiol Ricart, J. y GaYa NuÑo, J. A.: Arquitectura y Escultura románicas. Ars Hispanie, vol. V. Madrid, Edit. Plus Ultra, 1948.

Layna Serrano, F.: La arquitectura románica en la provincia de Guadalajara. Madrid, Nuevas Gráficas, 1935.

MADOZ, P.: Diccionario geográfico-estadístico-histórico. Madrid, 1850, tomo XVI.

Nonell, C.: El Románico en Guadalajara. Publicaciones de la Caja de Ahorros y Monte de Piedad de Zaragoza. Aragón y Rioja. s.I. 1974, 27 páginas.

PeCes y RatA, F. G.: Guía Histórica y catálogo del Museo Diocesano de Arte. SIGÜENZA. Sigüenza, Gráficas Carpintero, 1982, 40 páginas.

TORRES BALBAS, L.: “Los comienzos del arte románico". Castilla Artística e Histórica. Boletín de la Sociedad Castellana de Excursiones, II, 2. ${ }^{\text {a }}$ serie, 1918.

- "Los modillones de lóbulos: ensayo de análisis de la evolución de una forma arquitectónica a través de diez y seis siglos". Archivo Español de Arte y Arqueología, XII, 1936. 


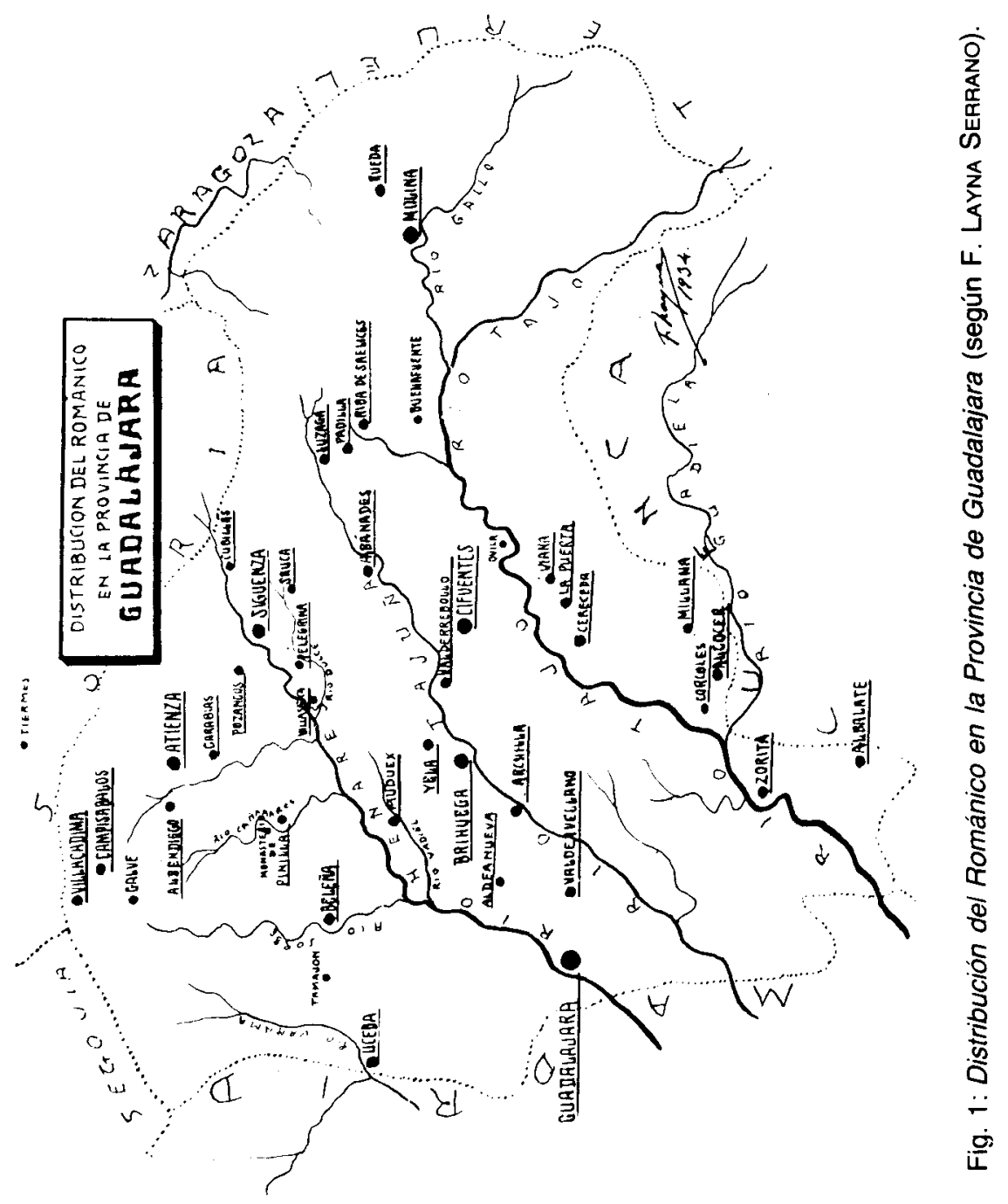




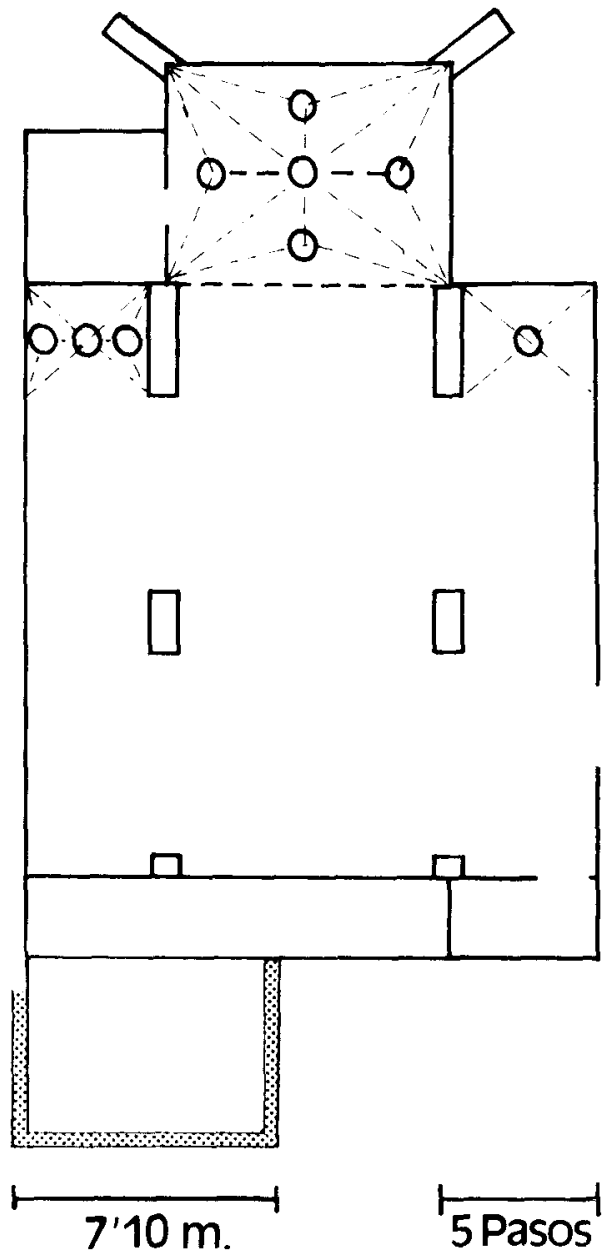

Fig. 3: Villacadima.

Iglesia de San Pedro.

7'10 m.

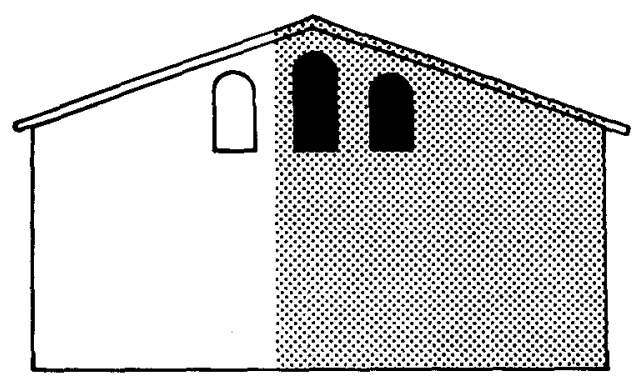

Fig. 2: Villacadima.

Iglesia de San Pedro. Reconstrucción ideal de la tachada de los pies antes de la construcción de la torre.
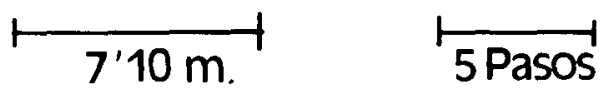


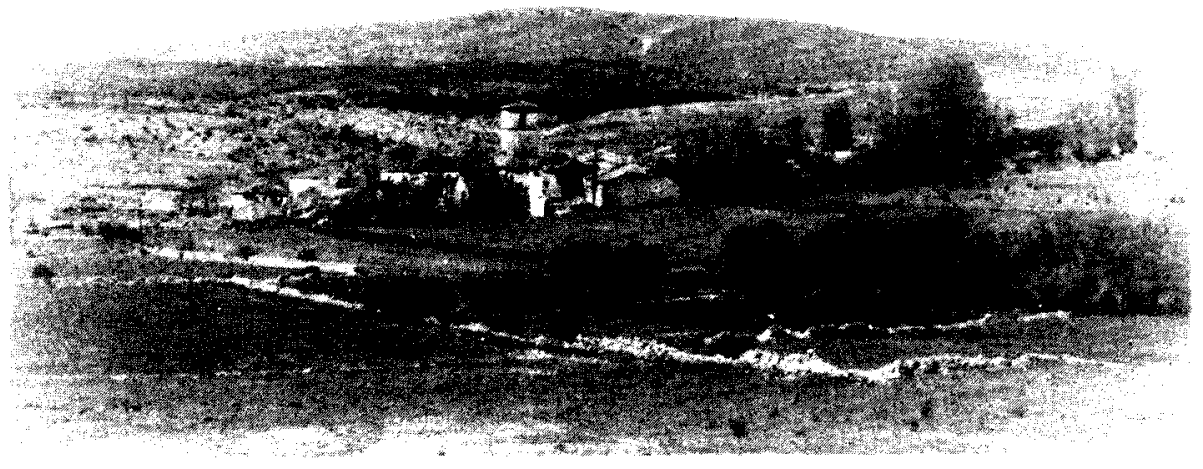

Fig. 4: Panorámica de Villacodima.

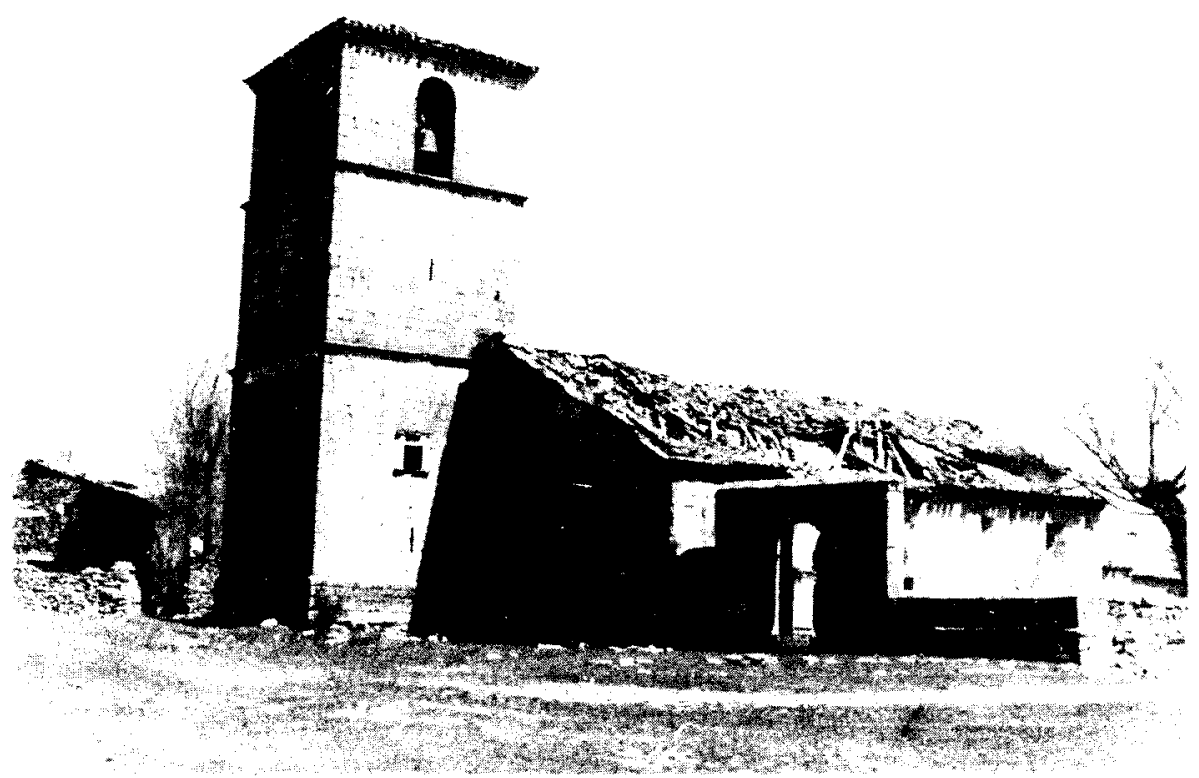

Fig. 5: La iglesia de San Pedro vista desde el sur, con la torre a los pies, y el arco de ingreso al atrio. 


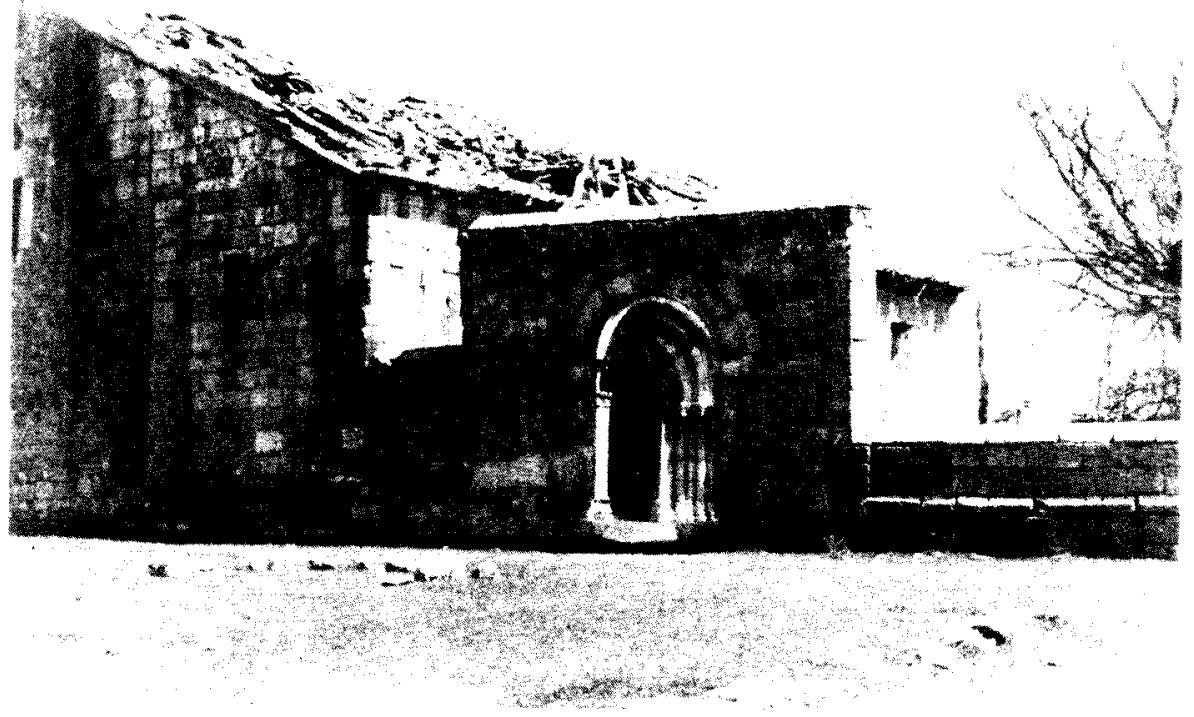

Fig. 6: Detalle del arco de ingreso al atrio a través del cual se observan parte de las arquivoltas de la portada románica.

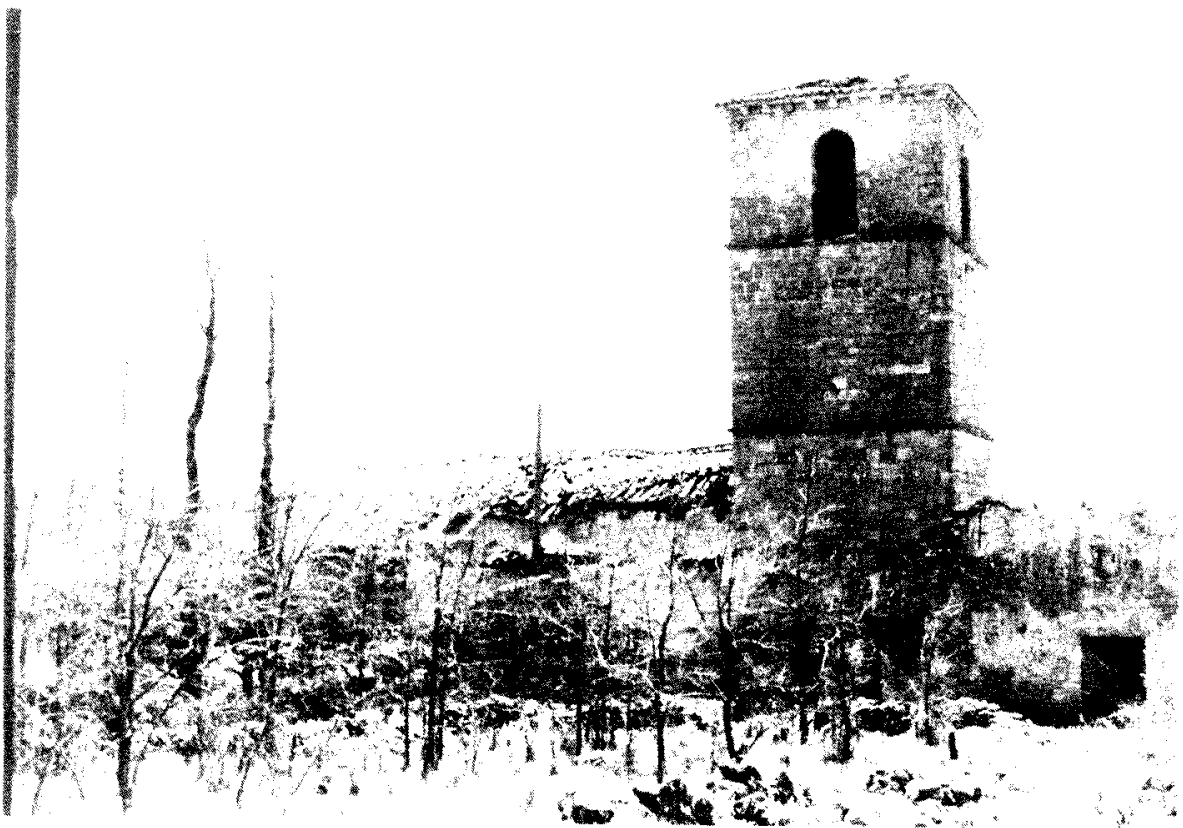

Fig. 7: La fachada norte de la iglesia con la torre a los pies. 


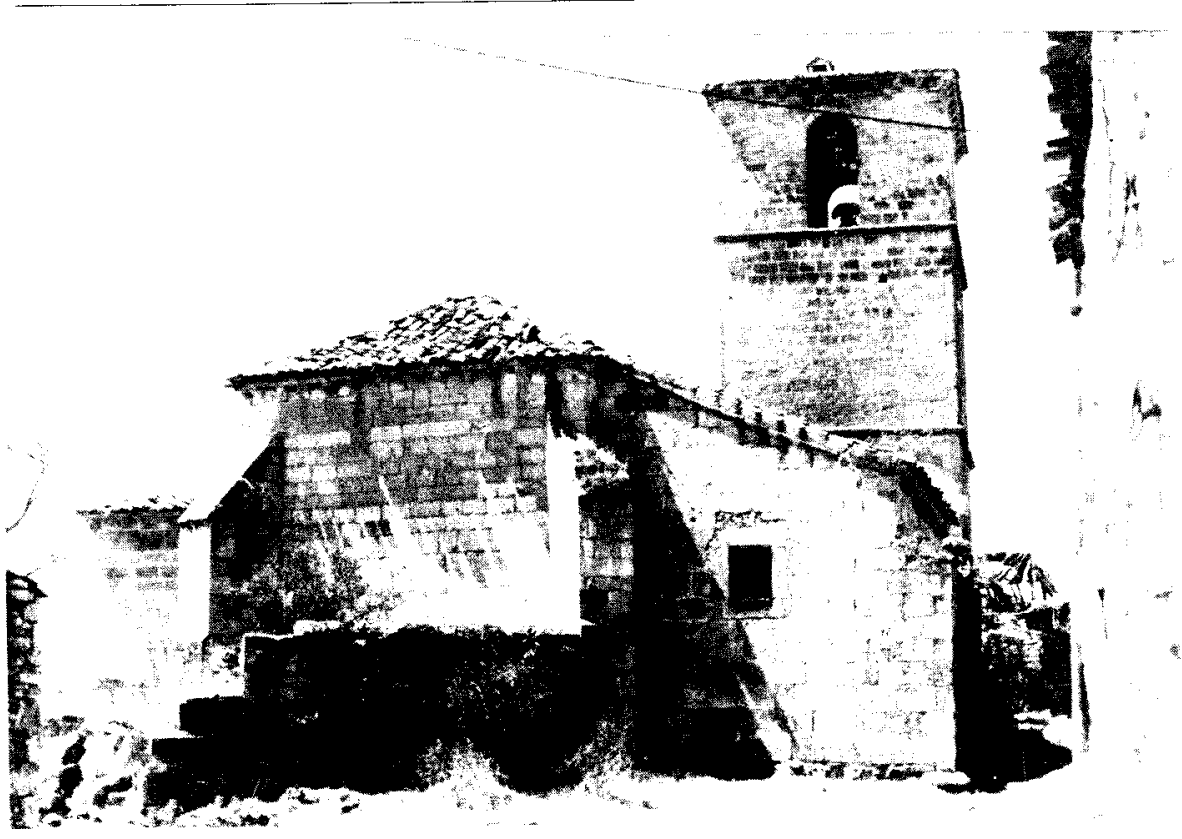

Fig. 8: Vista exterior del abside.

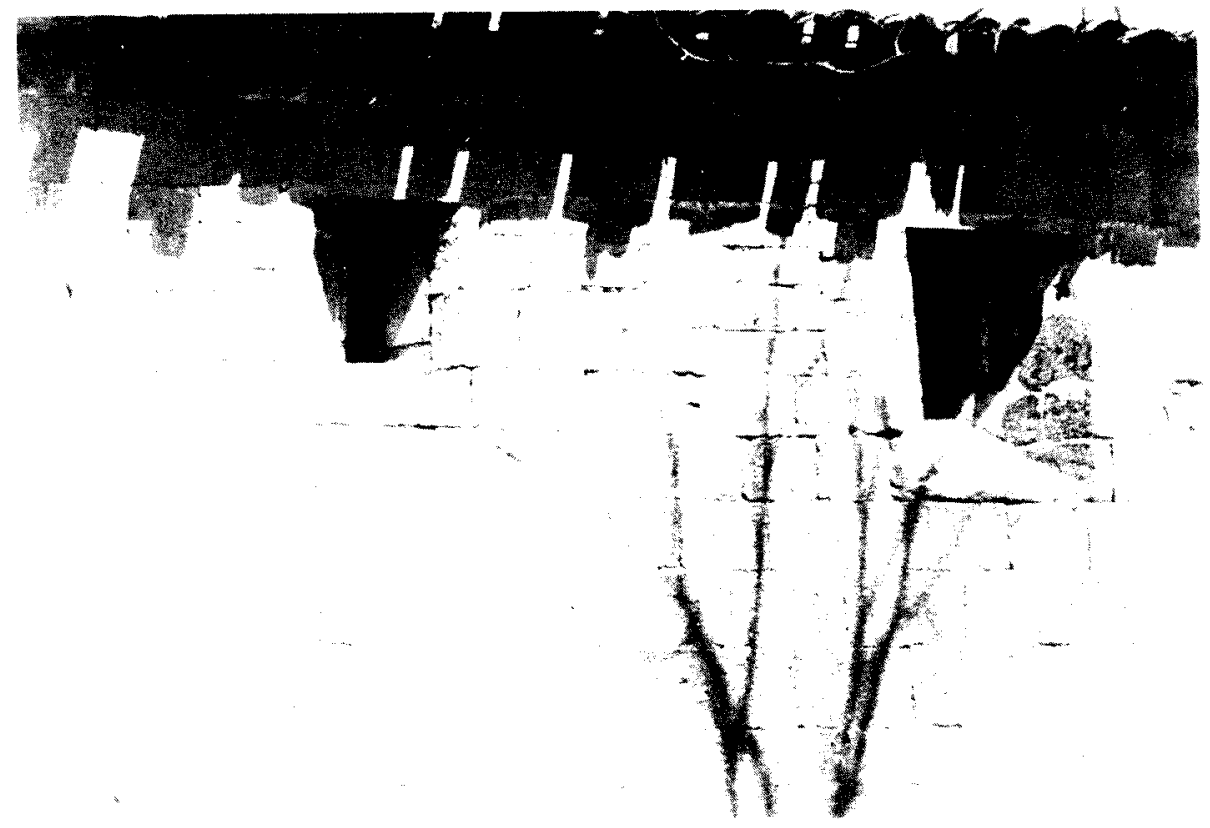

Fig. 9: Detalle de la fachada sur. 


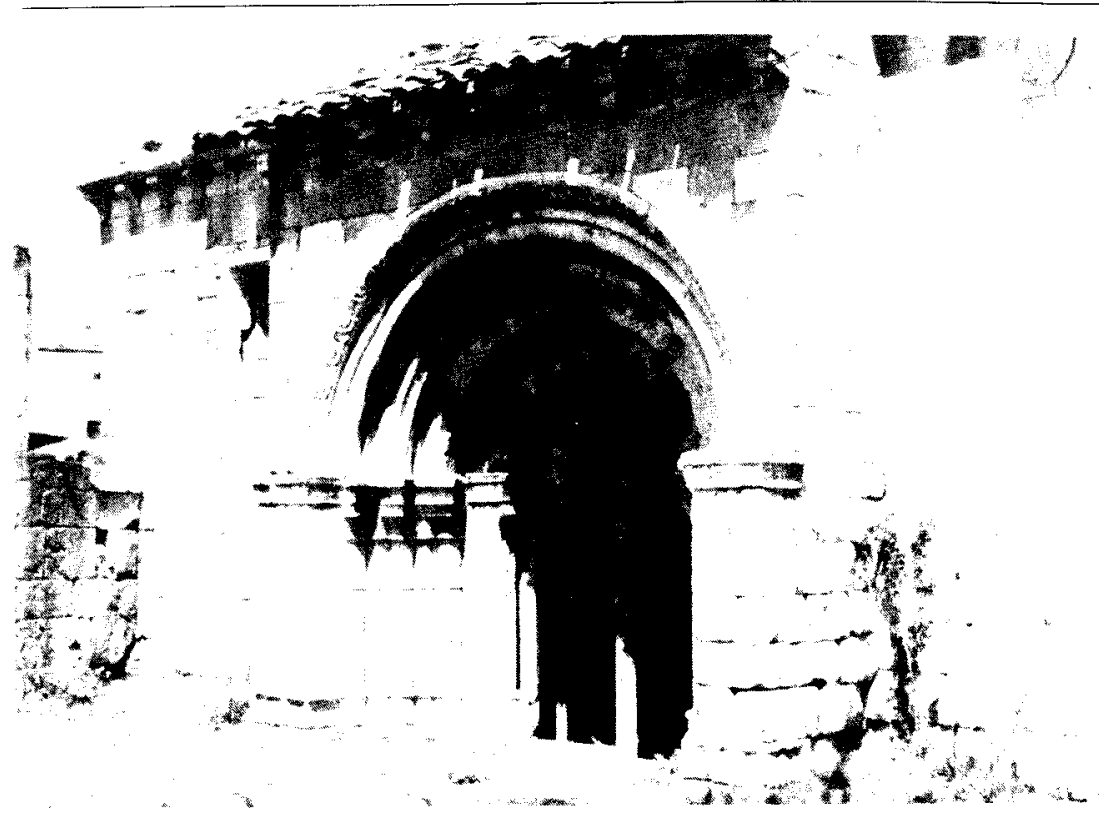

Fig. 10: La portada románica.

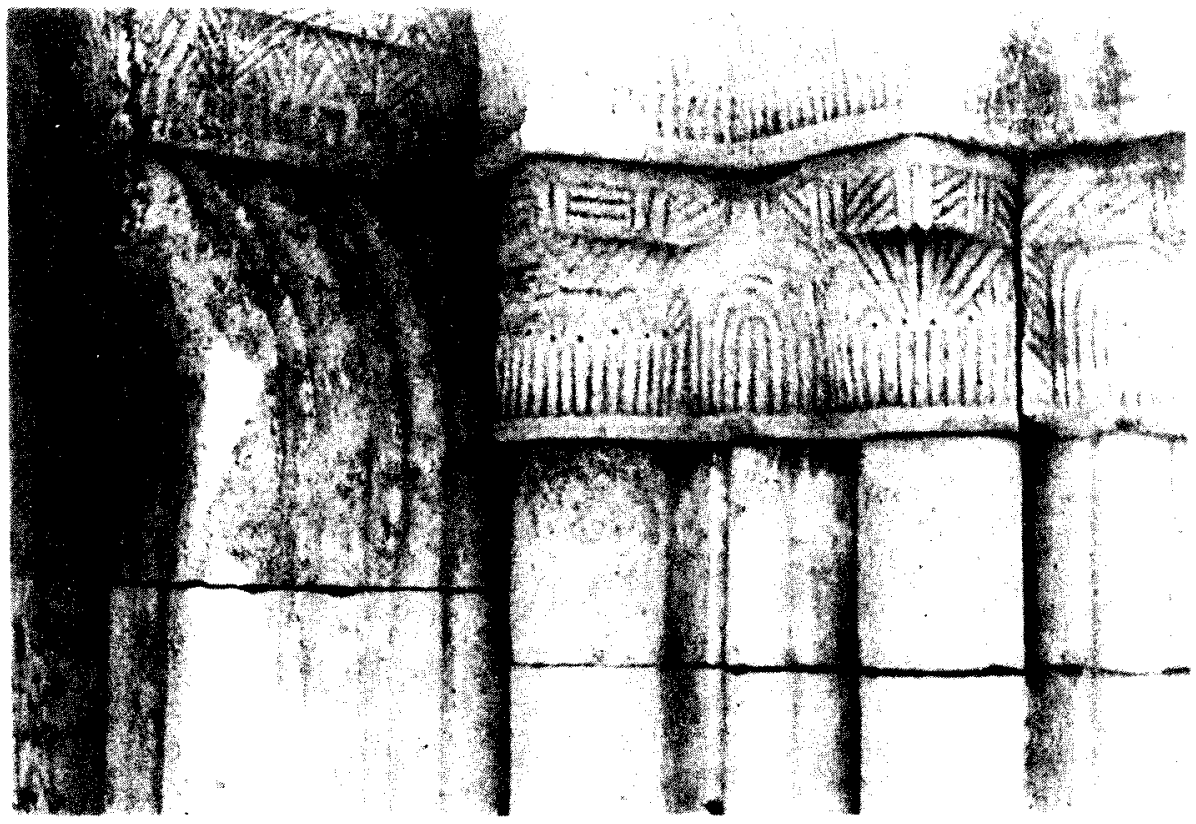

Fig. 11: Detalle de la decoración de las arquivoltas. 


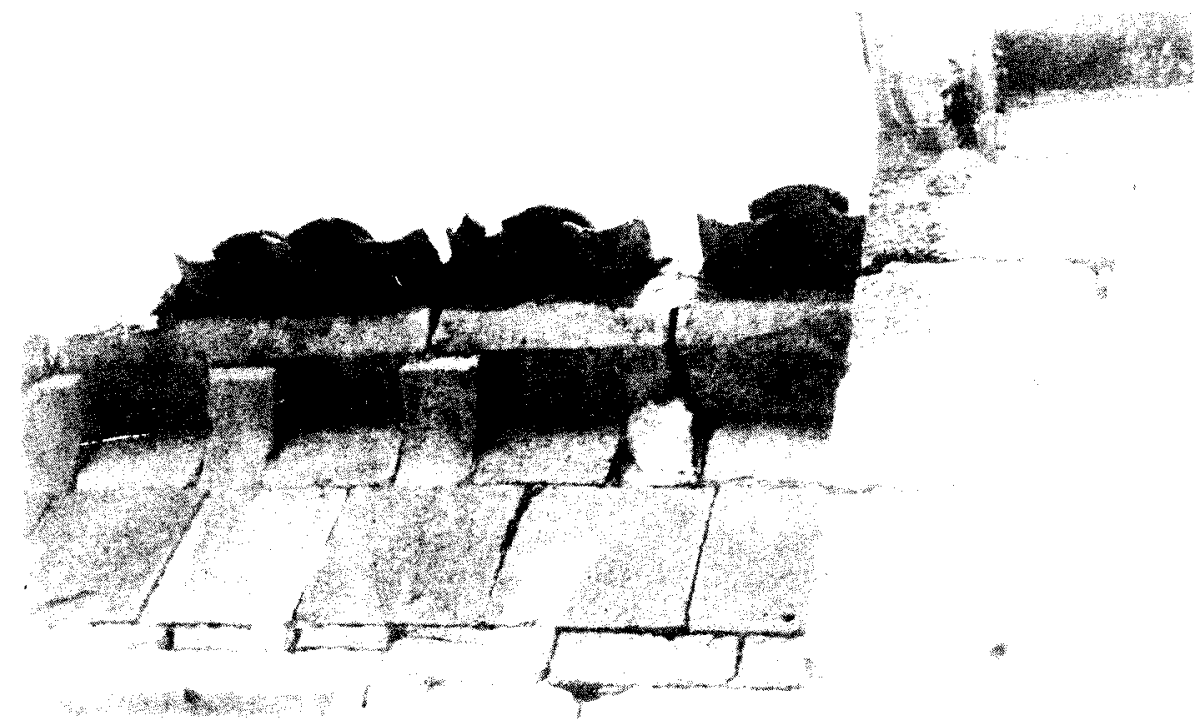

Fig. 12: Detalle de las mensulas de la fachada sur
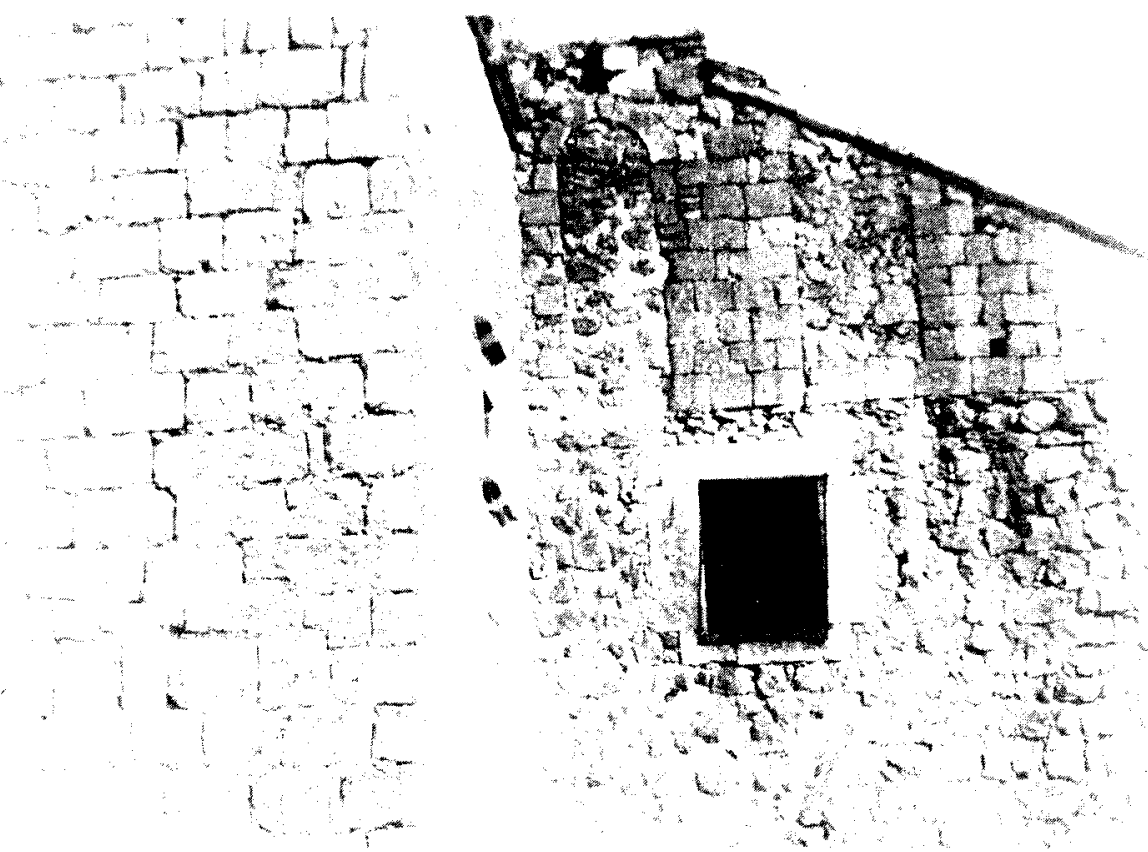

Fig. 13: Parte de la fachada occidental en la que sobresale el cuerpo de la torre y en la que se observan dos vanos con arcos de medic punto actualmente cegados. 


\section{ELENA MARIA ORTA GARCIA}

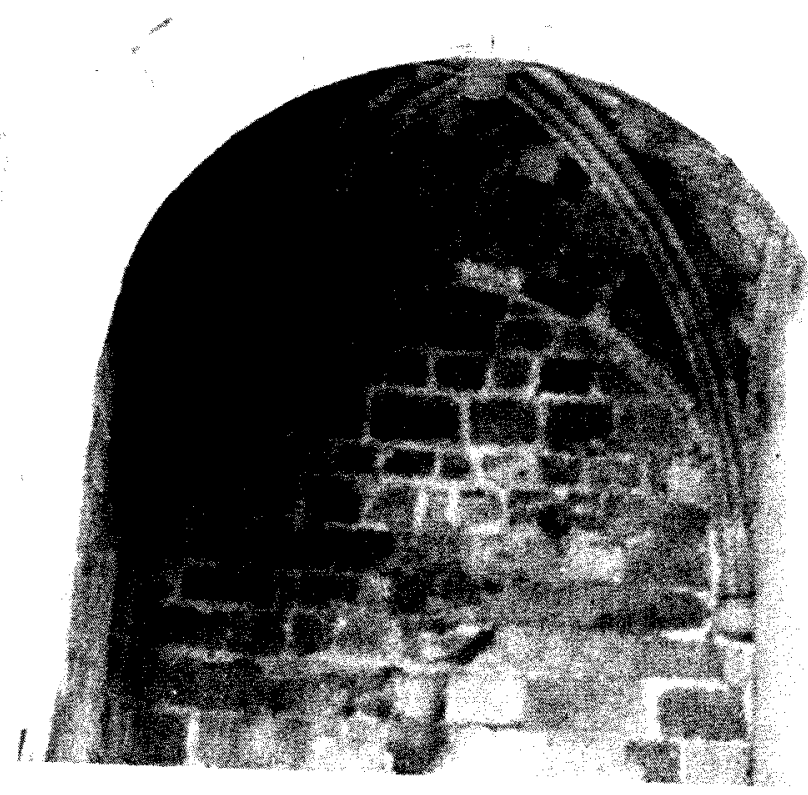

Fig. 14: Vista interior de la iglesia.

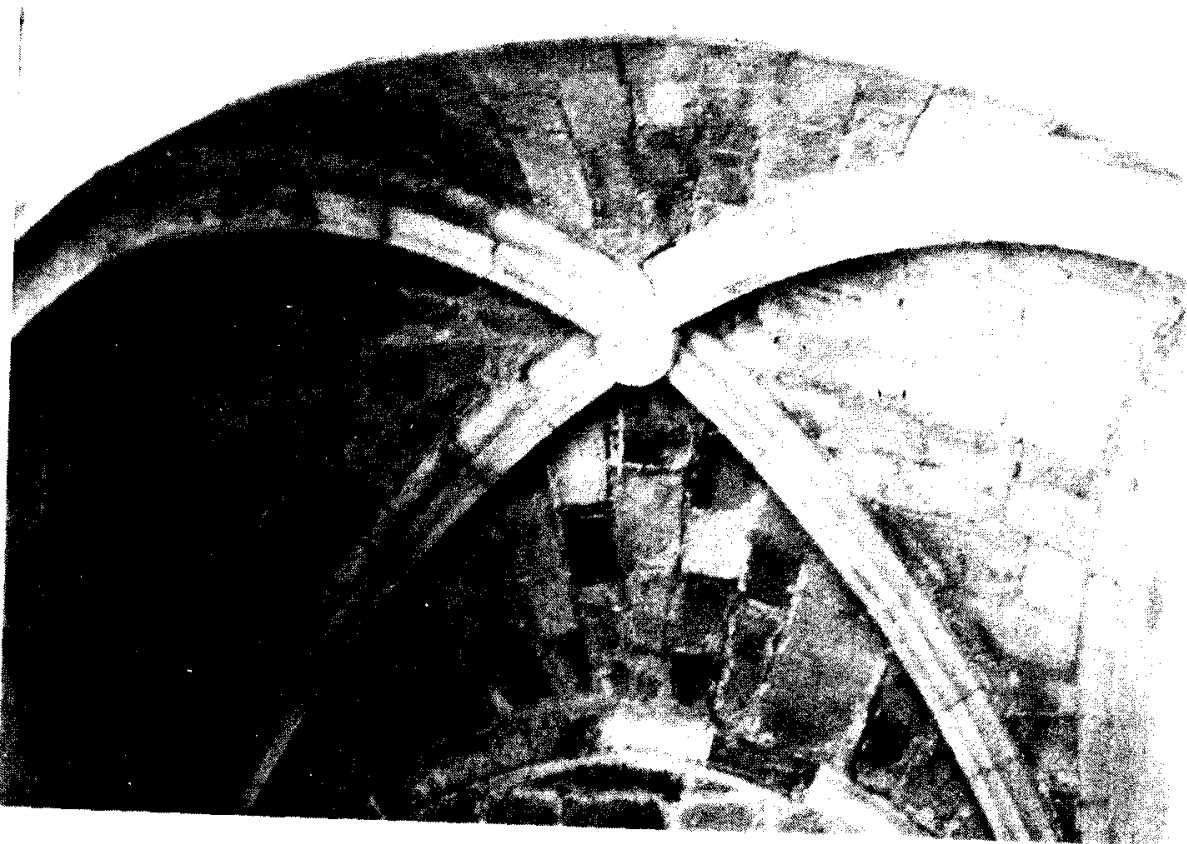

Fig. 15: Vista de la bóveda. 